\title{
Стратегия развития воспитания в Российской Федерации на период до 2025 года
}

\section{І. Общие положения}

Приоритетная задача Российской Федерации - формирование новых поколений, обладающих знаниями и умениями, которые отвечают требованиям XXI века, разделяющих традиционные нравственные ценности, готовых к мирному созиданию и защите Родины. Ключевым инструментом решения этой задачи является воспитание детей.

Стратегические ориентиры воспитания сформулированы Президентом Российской Федерации В. В. Путиным: «...Формирование гармоничной личности, воспитание гражданина России - зрелого, ответственного человека, в котором сочетается любовь к большой и малой родине, общенациональная и этническая идентичность, уважение к культуре, традициям людей, которые живут рядом».

Стратегия развития воспитания в Российской Федерации на период до 2025 года (далее Стратегия) призвана определить комплекс действий, адекватных динамике социальных, экономических и политических изменений в жизни страны, учитывающих особенности и потребности современных детей, социальные и психологические реалии их развития.

Конституция Российской Федерации провозглашает права и свободы человека, гражданский мир и согласие, исходя из общепризнанных принципов равноправия и самоопределения народов, уважения к памяти предков, передавших любовь и уважение к Отечеству, веру в добро и справедливость новым поколениям.

Стратегия, опираясь на Конституцию Российской Федерации, учитывает нормы Конвенции ООН о правах ребенка, международно-правовые нормы об основополагающих правах родителей.

Стратегия направлена на реализацию Указов Президента Российской Федерации, Федеральных законов Российской Федерации, в том числе Федерального закона от 24 июля 1998 года № 124-Ф3 «Об основных гарантиях прав ребёнка в Российской Федерации», Федерального закона от 29 декабря 2012 года № 273-Ф3 «Об образовании в Российской Федерации», а также постановлений Правительства Российской Федерации, иных нормативных правовых актов Российской Федерации.

Закон «Об образовании в Российской Федерации» гарантирует обеспечение воспитания как неотъемлемой части образования, взаимосвязанной с обучением, но осуществляемой и как самостоятельная деятельность, направленная на развитие личности, создание условий для самоопределения и социализации детей на основе социокультурных, духовнонравственных ценностей и принятых в обществе правил и норм поведения в интересах человека, семьи, общества и государства. Воспитанию уделяется большое внимание в принятых «Концепции государственной семейной политики в Российской Федерации на период до 2025 года» и «Концепции развития дополнительного образования детей».

Положения Стратегии взаимосвязаны с основными направлениями «Национальной стратегии действий в интересах детей на 2012-2017 годы» и предусматривают соответствие процесса развития личности детей национальному воспитательному идеалу, признание и поддержку определяющей роли семьи в воспитании детей. 
В условиях цивилизационных вызовов Стратегия направлена на усиление единения российского общества, переосмысление таких ценностей, как гражданская идентичность, патриотизм, ответственная жизненная позиция.

Стратегия призвана консолидировать усилия государства и общества, направленные на решение задач формирования российской идентичности подрастающего поколения. Стратегия утверждает главенство семьи в вопросах воспитания как деятельности направленной на изменение связей ребёнка с миром, с людьми, формирующей активную позицию личности. Стратегия закладывает основы системы противодействия националистическим, экстремистским вызовам и рискам современного детства.

Стратегия ориентирована на качественно новый общественный статус социальных институтов воспитания, обновление воспитательного процесса на основе оптимального сочетания отечественных традиций, современного опыта, достижений научных школ, предусматривающих культурно-исторический системно-деятельностный подход к социальной ситуации развития личностного потенциала детей и подростков.

Реализация Стратегии предполагает качественные изменения в отечественной системе воспитания, направленные на эффективное обеспечение таких личностных результатов развития детей, как их духовно-нравственные ценностно-смысловые ориентации, мотивация к непрерывному личностному росту, коммуникативные и другие социально значимые способности, умения и навыки, обеспечивающие социальное и гражданское становление личности, успешную самореализацию в жизни, обществе и профессии.

\section{II. Цель, задачи и основа Стратегии}

\section{Цель Стратегии:}

Определить приоритеты государственной политики в области воспитания детей, основные направления развития воспитания, механизмы и ожидаемые результаты реализации Стратегии, обеспечивающие становление российской гражданской идентичности, укрепление нравственных основ общественной жизни, успешную социализацию детей, их самоопределение в мире ценностей и традиций многонационального народа Российской Федерации, межкультурное взаимопонимание и уважение.

\section{Задачи Стратегии:}

создать условия для консолидации усилий институтов российского общества и государства по воспитанию подрастающего поколения на основе признания определяющей роли семьи;

обеспечить поддержку семейного воспитания на основе содействия ответственному отношению родителей к воспитанию детей, повышению их социальной, коммуникативной и педагогической компетентности;

повысить эффективность воспитательной деятельности в системе образования субъектов Российской Федерации;

сформировать социокультурную инфраструктуру, содействующую успешной социализации детей и интегрирующую воспитательные возможности образовательных, культурных, спортивных, научных, познавательных, экскурсионно-туристических и других организаций; 
обеспечить равный доступ к инфраструктуре воспитания детей, требующих особой заботы общества и государства, включая детей с ограниченными возможностями здоровья.

\section{Приоритеты государственной политики в области воспитания:}

воспитание детей в духе уважения к человеческому достоинству, национальным традициям и общечеловеческим достижениям;

поддержка определяющей роли семьи в воспитании детей, уважение к авторитету родителей и защита их преимущественного права на воспитание и обучение детей перед всеми иными лицами;

защита прав и соблюдение законных интересов каждого ребёнка;

обеспечение соответствия воспитания в системе образования традиционным российским культурным, духовно-нравственным и семейным ценностям;

обеспечение условий для физического, психического, социального, духовнонравственного развития детей, в том числе детей, находящихся в трудной жизненной ситуации (детей, оставшихся без попечения родителей; детей с ограниченными возможностями здоровья, детей - жертв вооруженных и межнациональных конфликтов, экологических и техногенных катастроф, стихийных бедствий; детей из семей беженцев и вынужденных переселенцев; детей, оказавшихся в экстремальных условиях; детей, отбывающие наказание в виде лишения свободы в воспитательных колониях и др.) формирование позиции личности по отношению к окружающей действительности;

воспитание языковой культуры детей;

развитие сотрудничества субъектов системы воспитания (семьи, общества, государства, образовательных, научных, традиционных религиозных и иных общественных организаций, организаций культуры и спорта, СМИ, бизнес-сообществ) в совершенствовании содержания и условий воспитания подрастающего поколения граждан Российской Федерации.

\section{III. Основные направления развития воспитания}

\section{1. Развитие социальных институтов воспитания}

\section{Поддержка семейного воспитания:}

содействие укреплению семьи и защита приоритетного права родителей на воспитание и обучение детей перед всеми иными лицами;

повышение социального статуса и общественного престижа отцовства, материнства, многодетности;

сохранение, укрепление и развитие культуры семейного воспитания детей на основе традиционных семейных и духовно-нравственных ценностей, с учетом роли традиционных религий России;

популяризация лучшего педагогического опыта воспитания детей в семьях, в том числе многодетных и приемных; 
содействие укреплению связей между поколениями, родственных связей, возрождению традиционной значимости больших многопоколенных семей;

создание условий для расширения участия семьи в воспитательной деятельности образовательных и других организаций, работающих с детьми, а также в управлении ими;

содействие повышению педагогической культуры родителей с участием образовательных и общественных организаций;

расширение инфраструктуры семейного отдыха, семейного образовательного туризма в каникулярное время;

поддержка семейных клубов, клубов по месту жительства, семейных и родительских объединений, содействующих укреплению семьи, сохранению и возрождению традиционных семейных и нравственных ценностей, культуры семейной жизни, усилению роли отца в семейном воспитании;

создание условий для просвещения и консультирования родителей по правовым, экономическим, медицинским, психолого-педагогическим и иным вопросам семейного воспитания.

\section{Развитие воспитания в системе образования:}

обновление содержания воспитания, внедрение форм и методов, основанных на лучшем педагогическом опыте в сфере воспитания и способствующих эффективной реализации воспитательного компонента федеральных государственных образовательных стандартов;

содействие разработке и реализации образовательных программ, включению в образовательные программы элементов, направленных на повышение уважения детей к семье и родителям, старшим поколениям, подготовку личности к браку и семейной жизни на основе традиционных семейных и нравственных ценностей;

полноценное использование воспитательного потенциала основных и дополнительных образовательных программ;

расширение вариативности воспитательных систем и технологий, нацеленных на формирование индивидуальной траектории развития личности ребёнка, с учётом его потребностей, интересов и способностей;

совершенствование условий для выявления и поддержки одаренных детей;

развитие форм включения детей в интеллектуально-познавательную, трудовую, общественно-полезную, художественную, физкультурно-спортивную, игровую деятельности на основе использования потенциала системы дополнительного образования;

развитие у подрастающего поколения интереса к чтению;

создание условий для повышения у детей уровня владения русским и родным языками и иными коммуникативными компетенциями; 
создание условий для психолого-педагогической поддержки воспитания в системе каникулярного отдыха и оздоровления детей.

\section{Расширение воспитательных возможностей информационных ресурсов:}

создание условий для позитивного развития детей в информационной среде (интернет, кино, телевидение, книги, СМИ, в том числе радио и телевидение);

содействие популяризации традиционных российских культурных, нравственных и семейных ценностей в информационном пространстве;

применение разнообразных средств защиты детей от информации, причиняющей вред их здоровью и развитию при предоставлении доступа к интернет-ресурсам.

\section{Поддержка общественных объединений в сфере воспитания:}

улучшение условий для эффективного взаимодействия детских и иных общественных объединений с образовательными организациями общего, профессионального и дополнительного образования в целях содействия реализации и развития лидерского и творческого потенциала детей;

поддержка родительских и иных общественных объединений, содействующих воспитательной деятельности в образовательных организациях;

широкое привлечение детей к участию в деятельности социально-значимых познавательных, творческих, культурных, краеведческих, благотворительных организациях и объединениях, волонтерском движении;

расширение государственно-частного партнерства в сфере воспитания детей.

2. Обновление воспитательного процесса с учетом современных достижений науки на основе отечественных традиций

\section{Гражданское и патриотическое воспитание:}

формирование у детей целостного мировоззрения, российской идентичности, уважения к своей семье, обществу, государству, принятым в семье и обществе духовно-нравственным и социокультурным ценностям, к национальному культурному и историческому наследию и стремления к его сохранению и развитию;

создание условий для воспитания у детей активной гражданской позиции, гражданской ответственности, основанной на традиционных культурных, духовных и нравственных ценностях российского общества, для увеличения знаний и повышения способности ответственно реализовывать свои конституционные права и обязанности;

развитие правовой и политической культуры детей, расширение конструктивного участия в принятии решений, затрагивающих их права и интересы, в том числе в различных формах самоорганизации, самоуправления, общественно-значимой деятельности;

развитие программ патриотического воспитания детей, в том числе военнопатриотического; 
разработка и реализация вариативных программ воспитания, способствующих правовой, социальной, культурной адаптации детей мигрантов;

формирование мотивов, нравственных и смысловых установок личности, позволяющих противостоять экстремизму, ксенофобии, дискриминации по социальным, религиозным, расовым, национальным признакам, межэтнической и межконфессиональной нетерпимости, другим негативным социальным явлениям.

\section{Духовно-нравственное развитие:}

воспитание у детей чувства достоинства, чести и честности, совестливости, уважения к отцу, матери, учителям, старшему поколению, сверстникам, другим людям;

развитие в детской среде ответственности и выбора, принципов коллективизма и солидарности, духа милосердия и сострадания, привычки заботиться о детях и взрослых, испытывающих жизненные трудности;

формирование деятельностного позитивного отношения к людям с ограниченными возможностями здоровья и детям-инвалидам, преодоление психологических барьеров, существующих в обществе по отношению к людям с ограниченными возможностями;

расширение сотрудничества между государством, обществом, традиционными религиозными общинами и иными общественными организациями и институтами в сфере духовно-нравственного воспитания детей.

\section{Приобщение детей к культурному наследию:}

создание равных для всех детей возможностей доступа к культурным ценностям;

увеличение доступности детской литературы для семей, приобщение детей к классическим и современным отечественным и мировым произведениям искусства и литературы;

поддержка мер по созданию и распространению произведений искусства и культуры, проведению культурных мероприятий, направленных на популяризацию традиционных российских культурных, нравственных и семейных ценностей;

создание и поддержка производства художественных, документальных, научнопопулярных, учебных и анимационных фильмов, направленных на нравственное и интеллектуальное развитие детей;

совершенствование деятельности библиотек;

создание условий для сохранения и поддержки этнических культурных традиций, народного творчества.

\section{Физическое развитие и культура здоровья:}

формирование у подрастающего поколения ответственного отношения к своему здоровью и потребности в здоровом образе жизни; 
создание равных условий для занятий физической культурой и спортом, для развивающего отдыха и оздоровления детей, включая детей с ограниченными возможностями здоровья, детей, находящихся в трудной жизненной ситуации, в том числе на основе развития спортивной инфраструктуры и повышения эффективности ее использования;

привитие культуры безопасной жизнедеятельности, профилактика вредных привычек;

формирование в детской среде системы мотивации к активному и здоровому образу жизни, занятиям спортом, развитие культуры здорового питания и трезвости;

распространение позитивных моделей участия в массовых общественно-спортивных мероприятиях.

\section{Трудовое воспитание и профессиональное самоопределение:}

воспитание у детей уважения к труду, людям труда, трудовым достижениям и подвигам;

формирование у детей умений и навыков самообслуживания, выполнения домашних обязанностей, потребности трудиться, добросовестного, ответственного и творческого отношения к разным видам трудовой деятельности;

развитие умения работать совместно с другими, действовать самостоятельно, активно и ответственно, мобилизуя необходимые ресурсы, правильно оценивая смысл и последствия своих действий;

содействие профессиональному самоопределению, приобщение детей к социальнозначимой деятельности для осмысленного выбора профессии.

\section{Экологическое воспитание:}

становление и развитие у ребенка экологической культуры, бережного отношения к родной земле;

формирование у детей экологической картины мира, развитие у них стремления беречь и охранять природу;

воспитание чувства ответственности за состояние природных ресурсов и разумное взаимодействие с ними.

\section{IV. Механизмы реализации Стратегии}

\section{Правовые:}

развитие и совершенствование федеральной, региональной и муниципальной нормативной правовой базы в сфере воспитания детей в соответствии с государственной политикой Российской Федерации в области воспитания;

совершенствование законодательной защиты определяющей роли семьи, приоритетного права родителей на воспитание и обучение детей, защиту их прав и интересов в системе воспитания. 


\section{Организационно-управленческие:}

разработка и реализация комплексных планов мер по реализации Стратегии на трёхлетние периоды;

принятие субъектами Российской Федерации в рамках региональных программ комплексных планов развития воспитания в соответствии со Стратегией, совершенствование в субъектах Российской Федерации условий для обеспечения эффективной воспитательной деятельности в образовательных и иных организациях на основе современных механизмов управления;

консолидация усилий воспитательных институтов на муниципальном и региональном уровнях;

эффективная координация межведомственного взаимодействия в системе воспитания;

сетевое взаимодействие общеобразовательных организаций, организаций дополнительного образования детей и иных организаций в сфере воспитания;

укрепление сотрудничества семьи, образовательных и иных организаций в воспитании детей;

системное изучение и распространение лучшего педагогического опыта работы в области воспитания;

создание системы показателей, критериев и индикаторов, определяющих эффективность воспитания в системе образования;

организация мониторинга эффективности реализации Стратегии в субъектах Российской Федерации, муниципальных образованиях.

\section{Кадровые:}

дальнейшее повышение престижа профессий педагога, воспитателя; создание атмосферы уважения к педагогическому труду, разработка мер по его поддержке;

развитие кадрового потенциала, в части воспитательной компетентности педагога, разработка и введение профессиональных стандартов специалиста в области воспитания;

содействие развитию педагогических компетенций у родителей;

модернизация системы педагогического образования, повышения квалификации и переподготовки специалистов в сфере воспитания с целью обеспечить соответствие содержания воспитательной деятельности вызовам современного общества;

\section{Научно-методические:}

проведение научных исследований в области воспитания и социализации детей;

развитие исследований в области семьи и семейного воспитания детей; 
проведение прикладных исследований по изучению роли и места СМИ, Интернета в развитии личности ребёнка;

разработка методического обеспечения реализации Стратегии;

\section{Финансово-экономические:}

создание в субъектах и муниципалитетах Российской Федерации необходимых ресурсов для развития эффективной деятельности социальных институтов воспитания;

обеспечение многоканального финансирования системы воспитания из федерального, региональных и местных бюджетов, а также за счет механизмов государственно-частного партнерства, привлеченных инвестиций, спонсорских средств;

создание и продуктивное использование гибкой системы стимулирования субъектов воспитательного процесса.

\section{Информационные:}

использование современных информационных и коммуникационных технологий, электронных информационно-методических ресурсов для обеспечения взаимодействия всех субъектов системы воспитания;

развитие сетевого взаимодействия образовательных организаций в интересах ребенка, дистанционных форм воспитания детей с ограниченными возможностями здоровья;

организация информационной поддержки Стратегии воспитания с привлечением значимых общероссийских и региональных СМИ; усиление воспитательного потенциала медиа-образования в образовательных организациях.

\section{V. Ожидаемые результаты}

Реализация Стратегии развития воспитания в Российской Федерации должна обеспечить:

значимость воспитания в общественном сознании;

укрепление российской гражданской идентичности, традиционных общенациональных ценностей, устойчивости и сплоченности российского общества;

повышение общественного престижа семьи, отцовства и материнства, сохранение и возрождение традиционных семейных ценностей, укрепление традиций семейного воспитания;

развитие общественно-государственной системы воспитания, основанной на координации и консолидации усилий всех ее институтов, современной развитой инфраструктуре, правовом регулировании, эффективных механизмах управления, конкурсного отбора и использования лучшего педагогического опыта воспитательной деятельности;

доступность для всех категорий детей качественного воспитания, способствующего удовлетворению их индивидуальных потребностей, развитию творческих способностей, независимо от места проживания, материального положения семьи, состояния здоровья; 
разработка и успешная реализация федеральных, региональных и муниципальных целевых программ поддержки одаренных детей, создание условий для развития их способностей в сфере образования, науки, культуры и спорта, независимо от их места жительства, социального положения и финансовых возможностей их семей;

укрепление и развитие кадрового потенциала системы воспитания;

утверждение в детской среде позитивных моделей поведения как нормы, снижение уровня негативных социальных явлений;

развитие и поддержка социально-значимых детских, семейных и родительских инициатив, обеспечение преемственности деятельности детских и молодежных общественных объединений;

повышение эффективности научных исследований в сфере воспитания;

повышение уровня информационной безопасности детей;

формирование системы осуществления мониторинга и показателей, отражающих эффективность реализации Стратегии. 